\title{
FOREIGN TRADE RELATIONS OF THE KHANATE OF BUKHARA
}

\author{
CJuraev B., Termez State University, Termez, Uzbekistan
}

\section{ВНЕШНИЕ ТОРГОВЫЕ ОТНОШЕНИЯ БУХАРСКОГО ХАНСТВА}

\section{(С)Джураев Б. Т., Термезский государственный университет, г. Термез, Узбекистан}

Abstract. In Bukhara Khanate, which has a history of about 250 years, had also done a number of trade activities. By the second half of the $16^{\text {th }}$ century, the Kazan and Astrakhan Khanates joined the Russian state. As the border of this state approached Central Asia, the trade relations between the Bukhara, Balkh, Khiva khanates and Russia were strengthened and permanent relationship developed. Bukhara officials send ambassadors several times to Russia in order to benefit their traders.

Аннотащия. Бухарское ханство, история которого насчитывает около 250 лет, также осуществило ряд коммерческих мероприятий. Во второй половине 16 века Казанское и Астраханское ханства вошли в состав Российского государства. По мере того как граница этого государства приближалась к Центральной Азии, торговые отношения между центральноазиатскими ханствами и Россией укреплялись. Развивались постоянные отношения. Правители Бухарского ханства несколько раз отправляли своих послов в Россию с целью обогащения своих торговцев.

Keywords: trade, historical work, taxes, written source, archive documents, border, Siberia, product, silk, cotton products, fabrics, industry.

Ключевые слова: торговля, исторические произведения, налоги, письменный источник, архивные документы, граница, Сибирь, товар, шелк, хлопковые изделия, материя, промышленность.

In the Shaybanid and the Ahtarhaniyah, the main wealth of the khan's treasury was profitable from trade, along with taxes and fines. A lot of information about it can be found in historical works, written sources and archive documents. The Khanate of Bukhara, which has a history of more than 250 years, also undertook a series of trade-related activities. Starting from the second half of the XVI century, when the khanates of Kazan and Astrakhan became a part of Russia and the borders of this state to the Central Asia came to an end, the trade relations between khanates of Central Asia - Bukhara, Balkh, Khiva and Russia were strengthened.

During his 40-year rule, Abdullakhan II paid attention to reconstruction of caravan routes, construction and repair of caravanseraies. Moreover, the first Central Asian trade was built in Bukhara in 1577 with a large commercial enclosure which was named after Abdullakhan[1, 248249].

So we can see that Abdullakhan II did certain things during the years of government. In the cities of Bukhara khanate and also in the surrounding areas there were separate mahallas, villages, which were specialized in certain types of production. For example, in the village of Zandona, 
located in the north of Bukhara, the production of a good quality cotton yarn was a thousand years old. Narshakhi wrote about this in the first half of the X century; cotton fabric, which is called zandona. This name was originally issued for the production of fabrics in this village. This fabric was produced in many Bukhara villages and they were also called as zandona makers [2, 11].

Narshakhi says that zandona fabric was very popular in Iraq, India, Iran, Karmana and other countries $[2,12]$.In the XVI-XVIII centuries and in the following period, zandona fabric was brought to Russia in large amounts. Here it was known as zendei $[4,46]$.

The political, economic connections of the Khanate of Bukhara with Eastern countries, especially India and Afghanistan have a long history. In the second half of the XVI century, the Khanate of Bukhara and India often sent envoys to each other. For example, in 1577, 1586, 1591 envoys were sent from Bukhara to India.

According to Narshakhi, Bukhara's Zandani fabric was very popular with foreign countries and taken to Iraq, India, Iran, Karmana and other countries [2, 12].

Economic relations between India and Central Asia mended visibly in the era of the Mongolian Empire. Priceless gem stones, crochet and other fabrics, paints, cashmere shawl, tea and such things were imported From India to Central Asia at that time. From Bukhara to India, mostly silk-based patterns and tablecloths, woolen fabrics, fur and carpets were taken. Termez and Sherabad cities played an important role in commerce relations of the Khanate of Bukhara with Afghanistan and India. In these cities, imported products were collected and exported to other regions of the Khanate. Each year, through Kelif and Sherabad, diverse goods were brought from Afghanistan to Bukhara on over 6,000 camels.

In trade relations between the Khanate of Bukhara and Afghanistan several cities notably, Mazari-Sharif, Shibirgan, Chor Province, Akhcha, Andhui, Saripul, Maymana played a central role $[7,30]$.

The Baburids' state was a southern neighbor of the Khanate Bukhara, the political and economic relations between the two countries were intense. Political-economic relations between the two countries had been routinely routed since the 70 's of the 16 th century. In this book, Nizamitdinov's book on 'the Relationship between Central Asia and India in the XVI-XVIII centuries" provides an extensive description of diplomatic and economic relations. The diplomatic relations between the two countries were repeated several times. Thus, in 1572, India's first ambassador to HijjaOltamish was sent to India by Abdullakhan. The next second embassy wich was led by Abdirahim, was also sent by Abdullah II. The next Indian ambassadors were sent to the palace of Abdullakhan in led by Mirza Pulat from the Sunnite branch of Islam. After many years Akbar decided to send an envoy to Bukhara. On May 17, 1597, ambassadors headed by Khoja Ashraf Nakshbandi from India to Bukhara [2, 23-71].

The relationship between the Khanate of Bukhara and Russia was mutually beneficial to both countries, involving relationship with Siberia. HadjiFarrukh explained on the attitude of the Khanate of Bukhara to the Russian state, saying that Abdulazizkhon wanted both sides to go on trading on a regular basis, saying that HojiFarrukh that's to say he had arrived with 9 pieces of tiger leather and 9 sets of Bukhara arrows. Then he added that the khan promised to give him and the Russian king 1 elephant, 2 white yaks, 18 horses, 2 steeds, 2 parrots, 2 tigers, 2 lynxes, silk and cotton fabric, cold weapons, invaluable stones and other gifts. Moreover, according to Hadji Sharif, Abdilazizkhon promised to exemption all Russian prisoners and let them return to their homeland and even he agreed to ensure the safety of the ambassador sent by Russian government to India [4, $66]$.

From the second half of the XVI century to the beginning of the XVII century, the Shaybanid rulers, particularly, during the reign of Abdulla II, periodically ruled over the embassy relations 
between the Khanate of Bukhara and the Baburids state and these relations maintained by two countries equally. It is possible to know that both countries were interested in the establishment of economic and political relations. The next embassies are connected with the rule of Ashtarkhanid dynasty. During the reign of the Ashtarkhanids there was an intense diplomatic relationship between the Khanate of Bukhara and the Baburids state. In 1632, VakkosHadji visited India; in 1633 India's embassies headed by Tarbiyatkhan reached to Balkh; after a long interval Khoja Ahmad al-Hussaini from the Khanate of Bukhara on 27 November, 1661, and then Kuchakbek in 1663 welcomed by Indian king. The Khanate of Bukhara was convened in July 1665 by Mustafa Hofi's embassy. In 1669, on 11 August, embassies led by Rustambiy from Bukhara came to India to respond to the Embassy of Yakkatozhan in May 1670. These visits were followed by several ones back and forth, in particular, Muhammad Sharif from Bukhara to India in 1671, Zabardasthan headed for Bukhara in 1685, Nazarbiy in 1688-1989 went to India, and the Sultanbiy's embassies arrived in India in 1714-1715 [2, 72]. It is possible to find out that such top-level embassy relations were primarily of the interests of political and economic relations. Let us talk about the economic (commercial) relations between the Khanate of Bukhara and the Baburid state. It should be noted that the main products were mainly medicinal products from India, various dyes, tea and dry and wet fruits from the Khanate of Bukhara. Researchers conclude that the trade relations between the Bukharan Khanate and the BaburidState had three main forms.

\section{Private trade.}

2. Sales carried out under the special representatives of the khan.

3. Mutual exchange of goods between the kings by sending gifts and donations to each other. Private merchants were mainly engaged in trade with rice products, which were significant for national needs. This will also be confirmed by the following information. During $16^{\text {th }}-18^{\text {th }}$ centuries various fabrics were imported to Bukhara markets from India; Bukhara exported wet and dried fruits, horses, camels, silk fabrics, beaver skins, linen cloth of Russians, and many others to India $[2,73]$.

The trade relations in the $17^{\text {th }}$ century between Bukhara and the Russian Empire, which were neighboring countries in played an important role in the diplomatic relations as well between the two countries. The Khanate of Bukhara mainly imported weapons for military purposes, armaments, steel and gunpowder.

On the roads, the horse, camel donkeys, and other animals served as to carry goods. This could be confirmed by the statement by English trader Anthony Jenkinson, who visited Bukhara, and stated: "All people in this country travel only with caravans" [5, 22-23].

It is interesting to look at Hanvey's knowledge of Thomson's reports, who visited Bukhara in 1741, to describe the silver coins in the time of Abulfayzhkan. According to his data, Bukharan people did not possess silver coins, and copper coins were considered as coins, and approximately 50-80 copper coins equaled a gold coin $[6,162]$.

Thus, silk proction played an important role in the Central Asian crafts industry, among which the silk fabrics the Fergana valley and Bukhara were considered to be an important part of the trade. Moreover, Filipp Efremov's remarks are noteworthy, although it is a short story about the production of fabrics in the Bukhara Khanate. According to him, silk, silver and gold embroidered fabrics, atlas, velvet, flower gowns, were found in this region. There was cotton produced in large amounts here. It provides information about tent, rug, gauze, rough cotton wool, transparent white scarf and other fabrics $[4,47]$. Although these words were dated to the XVIII century, the fabrics 
mentioned in the Central Asian cities were long ago. It is possible to know that these products were very popular in domestic and foreign trade.

Based on this information, Bukhara merchants are known to export overseas cotton, silk and ready-made products, as well as provide the domestic market with foreign products.

So, as mentioned above, we can find out that markets of the Khanate of Bukhara mainly exported cotton fiber goods to the foreign markets and for domestic markets they brought weapons and fur. During the reign of Shaybanids and Ashtarhanids, although international trade was carried out by water, but many measures had been undertaken to revive the Great Silk Road.

In conclusion, the strengthening of trade relations between The Khanate of Bukhara and other countries contributed to the reduction of the production of local crafts. However, the region's global market, especially in the fields of carpet weaving and karakul leather, not only satisfied the needs of the region but also became popular with the world market.

\section{References:}

1. Ziyo, A. (2000). The history of uzbek statehood. T.: Sharq, 197-198.

2. Frye, R. N. (Ed.). (1954). The history of Bukhara (Vol. 61). Medieval Academy of Amer.

3. Nizomiddinov, I. Ġ. (1966). XVI-XVIII asrlarda Ǔrta Osi. e-Ḩindiston munosabatlari. Ǔzbekiston SSR Fan Našri· eti.

4. Ziyaev, K. Z. (1983). Ekonomicheskie sviazi Srednei Azii s Sibir'iu v XVI-XIX vv. (Economic Relations between Central Asia and Siberia in 16th-19th Centuries).

5. Sultonova, G. (2017). Bukharan Relations with the Zunghar Khanate in the Early Modern Era: New Sources and New Insights//布哈拉汗國與準噶爾汗國之間的外交關係: 新發現的文獻 及解釋. Central Asiatic Journal, 60(1-2), 301-313. www.jstor.org/stable/10.13173/centasiaj.60.12.0301

6. Davlatov Sh. A. Stanovlenie denezhno-kreditnoi sistemy Respubliki Tadzhikistan. SPb. 2009.

7. Kabulov, E. A. (2020). Iz istorii stroitel'stva torgovogo puti Termez-Samarkand. Nauka, tekhnika i obrazovanie, (1 (65)).

\section{Список литературы:}

1. Ziyo A. The history of uzbek statehood. T.: Sharq. 2000. P. 197-198.

2. Frye R. N. et al. (ed.). The history of Bukhara. Medieval Academy of Amer, 1954. Vol. 61.

3. Nizomiddinov I. G. XVI-XVIII asrlarda Ǔrta Osi· e-Ḩindiston munosabatlari. Ǔzbekiston SSR Fan Našri eti, 1966.

4. Ziyaev K. Z. Ekonomicheskie sviazi Srednei Azii s Sibir'iu v XVI-XIX vv.(Economic Relations between Central Asia and Siberia in 16th-19th Centuries). 1983.

5. Sultonova G. Bukharan Relations with the Zunghar Khanate in the Early Modern Era: New Sources and New Insights//布哈拉汗國與準噶爾汗國之間的外交關係: 新發現的文獻及解釋 // Central Asiatic Journal. 2017. Vol. 60. №1-2. P. 301-313. www.jstor.org/stable/10.13173/centasiaj.60.1-2.0301 
6. Давлатов Ш. А. Становление денежно-кредитной системы Республики Таджикистан. СПб. 2009.

7. Кабулов Э. А. Из истории строительства торгового пути Термез-Самарканд // Наука, техника и образование. 2020. №1(65).

Работа поступила

в редакцию 24.01.2020 г.
Принята к публикаиии 30.01 .2020 2.

Ссылка для ичитирования:

Juraev B. Foreign Trade Relations of the Khanate of Bukhara // Бюллетень науки и практики. 2020. Т. 6. №3. С. 545-549. https://doi.org/10.33619/2414-2948/52/64

Cite as (APA):

Juraev, B. (2020). Foreign Trade Relations of the Khanate of Bukhara. Bulletin of Science and Practice, 6(3), 545-549. https://doi.org/10.33619/2414-2948/52/64 